\title{
Arsitektur Neo Vernakular pada Gedung Pertunjukan Seni Tari Tradisional Suku Dayak di Samarinda
}

\author{
Fauzi Syah $^{1}$, Suci Ramadhani ${ }^{2}$, Esty Poedjioetami ${ }^{3}$ \\ 1,2,3Jurusan Arsitektur, Fakultas Teknik Sipil dan Perancangan, Institut Teknologi Adhi Tama Surabaya, \\ Surabaya, Indonesia \\ e-mail: . $_{\text {fauzisyah2510@gmail.com }}$
}

\begin{abstract}
Samarinda refers to the capital city of East Kalimantan Province which has numerous cultures including traditional dance art namely typical dance of Dayak tribe. Therefore, this research planned and designed the building for showing the performance of Dayak Tribe Traditional Dance Art in Samarinda by the theme of Neo Vernacular Architecture. It aims at developing the typical dance from East Kalimantan. The theme of Neo Vernacular Architecture and the macro concept (Developing culture) are implemented by creating a design which can preserve local elements formed empirically by a tradition. The micro concept of land order (Cultural Realm) Creating a land structure design by applying an area that has a comfortable and beautiful atmosphere and applying the cultural values of the Dayak tribe to the area, whereas the micro concept of shape (Forward Culture) presents a design of building shape also having the concept of advanced culture to motivate the development of local typical culture. The micro concept of space (Adaptive) develops spaces design which is directly or indirectly interconnected with each other. The spaces will be able to facilitate the activities. Thus, this design is expected to be the centre for Dayak tribe typical dance art which can give positive contribution to the environment and people as well as become the tourism object for both domestic and foreign tourists who are interested in the dance art originated from East Kalimantan in Samarinda.
\end{abstract}

Keywords: Dance Art Performance Building, Neo-Vernacular Architecture, traditional, Dayak Tribe

\begin{abstract}
Kota Samarinda merupakan Ibukota provinsi Kalimantan Timur dan didominasi oleh warga Suku Dayak yang memiliki kesenian khas salah satunya berbentuk tarian khas Suku Dayak. Gedung Pertunjukan Seni Tari Tradisional Suku Dayak di Kota Samarinda dengan menggunakan tema aritektur Neo-Vernakular bertujuan untuk mengembangkan kesenian tari khas dari Kalimantan Timur. Pendekatan tema arsitektur Neo Vernakular bertujuan untuk melestarikan genius loci yang ada serta terbentuk secara empiris oleh tradisi, sehingga rancangan ini menerapkan konsep makro Develop Culture. Mikro KonsepTatanan Lahan (Cultural Realm) Menciptakan desain tatanan lahan dengan menerapkan sebuah kawasan yang memiliki suasana nyaman dan asri serta menerapkan nilai-nilai budaya Suku Dayak pada kawsan. Mikro Konsep Bentuk (Forward Culture) Menciptakan desain bentuk bangunan dengan konsep budaya yang maju, agar dapat memberikan semangat untuk mengembangkan kebudayaaan khas daeerah. Mikro Konsep Ruang "Adaptive" bertujuan untuk menciptakan ruang langsung maupun tak langsung, ruang fisik maupun imajiner, yang berfungsi sebagai wadah kegiatan. Hasil rancangan ini diharapkan menjadi pusat kesenian tari khas Suku Dayak yang dapat memberikan kontribusi positif bagi lingkungan dan masyarakat serta dapat menjadi obyek wisata bagi masyarakat, baik dari dalam maupun luar negeri yang tertarik tentang kesenian tari asli Kalimantan Timur di Kota Samarinda.
\end{abstract}

Kata Kunci: Pertunjukan Seni Tari, Arsitektur Neo-Vernakular, Trian khas Suku Dayak 


\section{Pendahuluan}

Kalimantan Timur memiliki jumlah penduduk yang cukup besar seiring dengan perkembangan kota. Bberagam suku tinggal disana, baik suku asli maupun suku dari luar daerah. Suku dari luar yang berdatangan dan menetap disana antara lain suku Bugis, suku Banjar, suku Jawa, suku Madura, suku Tionghoa. Suku Dayak dan suku Kutai merupakan Suku asli dari Kalimantan Timur. Perkembangan Kota memicu peningkatan pendatang baru ke Kalimantan Timur, penduduk asli dari suku Kutai dan Suku Dayak banyak yang berpindah ke pesisir atau pedalaman. Kutai merupakan suku yang mendiami daerah kota dan pesisir. Pada masa kini telah terjadi proses asimilasi dengan suku-suku pendatang sehingga sudah mulai kehilangan ciri khasnya, berbeda dengan Suku Dayak yang sampai sekarang masih memegang teguh tradisi sehingga memiliki ke khasan Kalimantan dalam setiap aspek kehidupannya (tarian, bahasa, bertanam, berburu dan lain-lain sebagainya).

Kota Samarinda memiliki potensi dari segi pariwisata maupun budaya dan akan dikembangkan menjadi kota wisata menurut RTRW. Menurut Sanjaya dan Kartono (2014) faktor yang menunjang samarinda sebagai kota wisata antara lain: 1)samarinda merupakan gerbang menuju pedalaman Kalimantan Timur 2) terdapat proyek bandara internasional disana sehingga hal ini akan mendukung perkembangan kota dan provinsi Kallimantan Timur. 3) Terdapat banyaknya ragam budaya di Kalimantan timur diantaranya ada seni tari tradisional yaitu tari khas Suku Dayak. Budaya lokal yang kurang dikenal oleh generasi muda terutama bagi pemuda asli daerah merupakan alasan utama pelestarian budaya daerah. Arsitektur tradisional Dayak dengan penekanan arsitektur lokal yang nantinya konsep ide atau gagasan dengan menggali dan menemukan tradisi dari kebudayaan bangunan yang sudah ada yang akan di aplikasikan ke dalam bentuk baru.

Dengan dibangunannya gedung pertunjukan seni tari tradisional di Samarinda sebagai wadah untuk mengembangkan kesenian tari khas dari Kalimantan Timur agar tidak hilang di makan zaman, dan anak cucu kita nanti bakal tau seperti apa kesenian warisan dari nenek moyang dulu. Gedung pertunjukan seni tari tradisional di Samarinda ini juga dapat menarik para wisatawan buat berkunjung ke Samarinda untuk melihat keunikan dari warisan budaya Suku Dayak khas Kalimantan Timur.

Kendala yang di alami dalam perencanaan Gedung Pertunjukan Seni Tari Tradisional Suku Dayak di Samarinda yaitu adalah bagaimana mewujutkan sebuah gedung pertunjukan seni tari tradisional Suku Dayak dengan menerapkan tema Arsitektur Neo Vernakular, serta mewujudkan bentuk bangunan yang mempertahankan nilai budaya dengan Arsitektur Neo Vernakular agar dapat mempertahankan arsitektur tradisional asli dari Suku Dayak.

\subsection{Arsitektur Neo-Vernakular sebagai Tema dan Konsep Perancangan pada Wilayah Berkebudayaan Dayak}

Arsitektur Neo Vernakular termasuk salah satu konsep arsitektur yang berkembang pada era Post Modern. Post modern adalah aliran dan langgam arsitektur yang muncul pada pertengahan 1960-an, munculnya pemikiran post modern dikarenakan adanya kritikan atas arsitektur modern oleh beberapa Arsitek ternama seperti Charles Jencks. Arsitektur Modern dianggap memberikan bentuk yang monoton dan Arsitek-arsitek postmodern menginginkan adaya bentuk serta pendekatan yang baru pada sebuah desain. (Fauzan \& Prayogi, 2020)

Arsitektur vernakular yang berada pada posisi arsitektur modern awal yang selanjutnya berkembang menjadi neo vernakular pada masa modern akhir setelah adanya kritikan terhadap arsitektur modern (Zikri, 2012), maka muncul kriteria yang mempengaruhi arsitektur neo vernakular yaitu sebagai berikut:

1. Bentuk-bentuk yang menerapkan unsur budaya dan lingkungan, termasuk iklim setempat, yang diungkapkan dalam bentuk fisik arsitektural (tata letak denah, detail, struktur dan ornamen)

2. Tidak hanya elemen fisik yang diterapkan dalam bentuk modern, tetapi juga elemen nonfisik seperti budaya pola pikir, kepercayaan, tata letak yang mengacu pada makro kosmos dan lainnya.

3. Produk pada bangunan ini tidak murni menerapkan prinsip-prinsip bangunan vernakular melainkan menghasilkan karya yang baru (mengutamakan penampilan visualnya). 
Perencanaan dan Perancangan, Perencanaan adalah suatu proses berpikir manusia dan tindakan yang berdasarkan dari pikiran tersebut (Tutuko, 2005). Sedangkan perancangan dapat berarti juga sebagai sebuah problem solving (proses penyelesaian masalah). Seorang perancang akan menghasilkan karya yang merujuk pada permasalahan yang ada, baik itu masalah dari isu lingkugan, sosial, ekonomi, budaya, dan lainnya. Lingkup rancangan ini bisa besar (skala kota) maupun kecil (skala produk atau benda).

Tari Tradisional, adalah suatu tarian yang berkembang di suatu daerah tertentu yang berpedoman luas dan berpijak pada adaptasi kebiasaan secara turun temurun yang dipeluk/dianut oleh masyarakat yang memiliki tari tersebut (Lail \& Widad, 2015). Tari tradisional umumnya memiliki filosofi tertentu serta nilai historis tinggi, mempunyai pedoman, juga berpijak pada adaptasi adat serta budaya lingkungan sekitar tempatnya.

Suku Dayak, Dayak merupakan nama kolektif suku asli Kalimantan. Secara umum yang menghuni pedalaman Kalimantan masuk dalam kelompok Suku Dayak. Kalimantan kawasan pantai atau daerah hilir biasanya dihuni oleh Melayu, Banjar, Bugis, Makassar, Cina, Jawa, Madura dan sukusuku lainnya. Mayoritas orang Melayu di Kalimantan merupakan keturunan Suku Dayak yang kemudian memeluk agama lslam. Singarimbun (1991) mengatakan sekitar 90 persen Melayu Kalimantan adalah keturunan Dayak, pada tahun 1986, orang Dayak diperkirakannya sebanyak kira-kira tiga juta jiwa dan orang Melayu lebih dari enam juta jiwa. Suku Dayak lebih suka disebut Daya karena bagi mereka Istilah Dayak mempunyai konotasi merendahkan (Coomans, 1987). Terutama di masa silam, saat mendengar kata Dayak, interpretasi orang berkaitan dengan keterbelakangan, kebiasaan mengayau, animisme, dan lain-lain dan saat ini konotasi tersebut mulai menghilang. Menurut Dr. Fridolin Ukur yang berasal dari Suku Dayak Ma'anyan. Dayak tidak perlu diganti dengan Daya. Untuk meningkatkan harkat dan kebanggaan akan suku untuk masyarakat Dayak, sudah didirikan perkumpulan-perkumpulan yang memakai istilah Dayak, antara lain: Sarekat Dayak dan Pakat Dayak sejak zaman Belanda.

Dari berbagai wacana di ataas, maka perancangan arsitektural di wilayah yang erat akan budaya Dayak, tepat untuk mewadahi aktifitas seni tari. Salah satu wadah untuk mewadahi aktivitas seni tari tradisional Dayak, adalah gedung pertunjukan. Dalam perancangangannya, gedung pertunjukan dapat menggunakan Arsitektur Neo-Vernakular sebagai Tema maupun Konsep perancangan.

\section{Metodologi}

Menggunakan metode penelitian kualitatif yaitu dengan menggunakan data-data dokumen sebagai data primer. Data-data tersebut dikumpulkan menggunakan: (1) Teknik Observasi yaitu dengan pengamatan langsung di lapangan. Adapun metode yang digunakan dalam mengumpulkan data langsung di lapangan yaitu dengan (a) Wawancara. (b) Dokumentasi. (c) Metode Literatur. (2) Studi Pustaka yaitu mengumpulan data yang dilakukan dengan mempelajari buku-buku referensi, laporanlaporan, majalah-majalah, jurnal-jurnal dan media lainnya yang berkaitan dengan obyek penelitian.

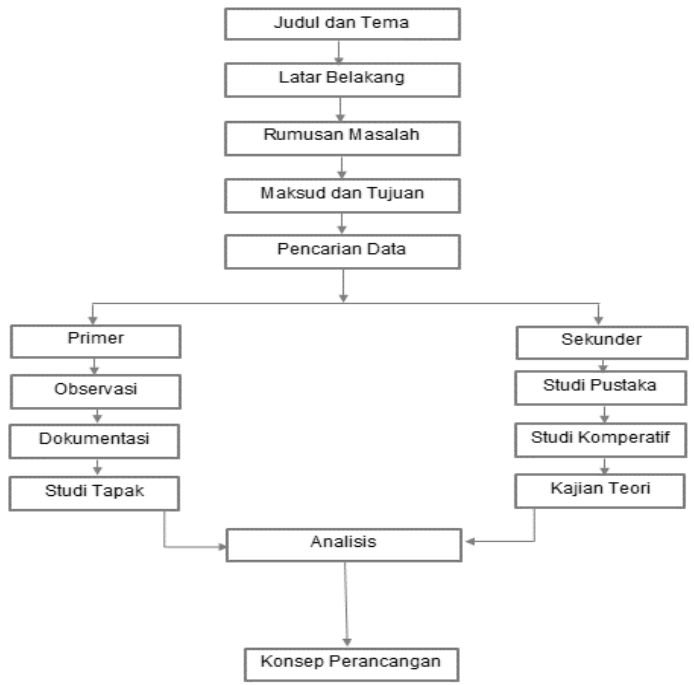

Gambar 1. Metode 
Tujuan dari penelitian yang dilaksanakan ini, antara lain:

1. Mengidentifikasi permasalah serta isu-isu yang terkait dengan perencanaan dan perancangan Gedung Pertunjukan Seni Tari Tradisional Suku Dayak di Samarinda

2. Mengakaji landasan program arsitektural terkait perencanaan dan perancangan Gedung Pertunjukan Seni Tari Tradisional Suku Dayak di Samarinda

\section{Hasil dan Pembahasan}

\subsection{Studi Banding}

Studi banding diperlukan untuk mendapatkan rancangan desain yang mendekati ideal, dengan cara membandingkan dan mengamati obyek - obyek studi yang sudah ada melalui studi kasus lapangan dan studi kasus literatur.

\section{a. Desa Pampang Budaya Suku Dayak (Lapangan)}

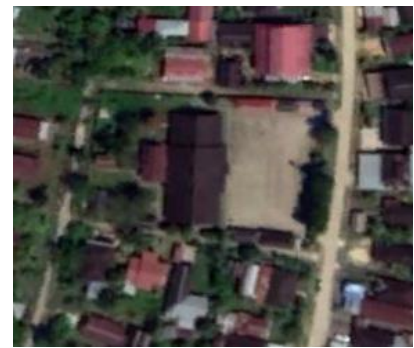

(a)

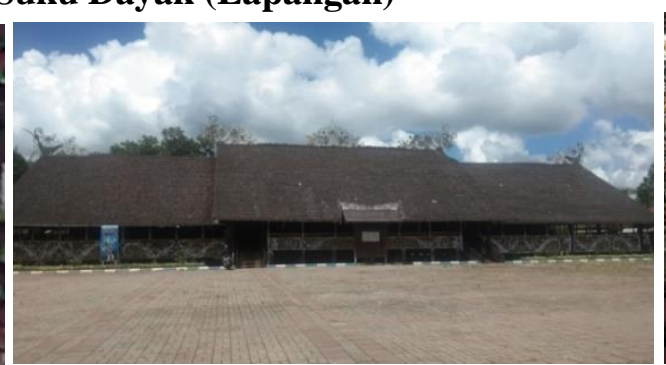

(b)

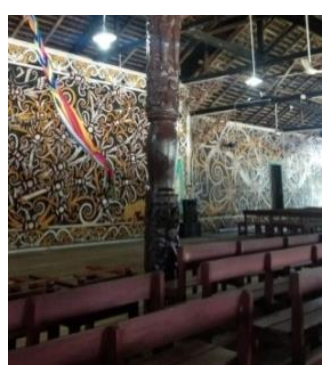

(c)

Gambar 2. (a) Site Plan (b) Tampak Depan (c) Interior

Desa Pampang berlokasi di Kelurahan Budaya Pampang Kecamatan Samarinda Utara Kotamadya Samarinda. Desa Pampang merupakan kawasan wisata budaya yang menyajikan kehidupan masyarakat Dayak Kenyah. Keunikan dari desa Pampang tersebut ialah warganya tetap mempertahankan budaya nenek moyang sebagai tradisi yang terus mereka lestarikan, serta keunikan lainnya dari desa pampang adalah rumah lamin khas Dayak yang di keilingi dengan ornament ukiran khas suku Dayak yang memiliki arti tersendiri. Masyarakat Dayak Kenyah di desa Pampang masih mempertahankan tradisi nenek moyang mereka yaitu memanjangkan telinga.

\section{b. Ciputra Artpreneur Theatre}

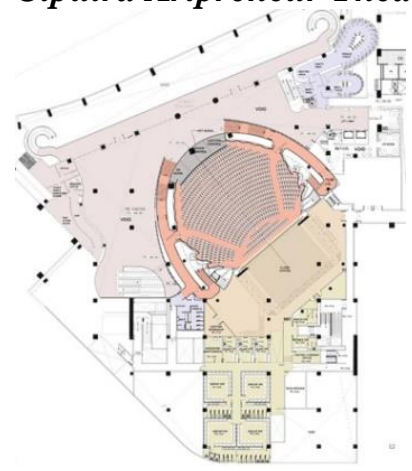

(a)

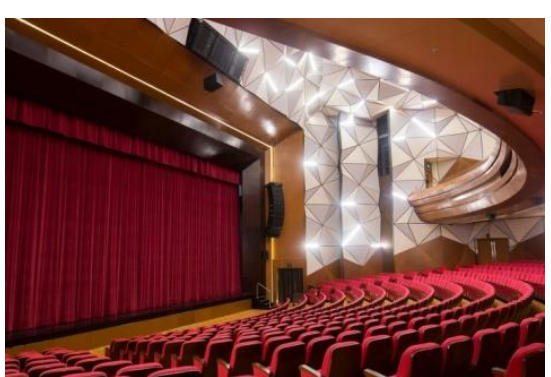

(b)

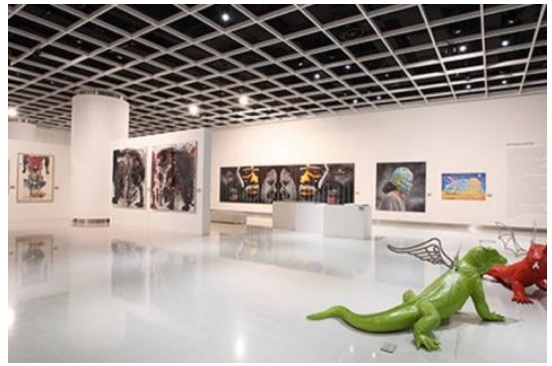

(c)

Gambar 3. (a) Site Plan (b) Ruang Teater (c) Ruang Pameran

Ciputra Artpreneur Theatre merupakan gedung teater yang berstandar internacional yang ada di Indonesia. Teater Ciputra Artpreneur menempati seluruh lantai 13. Ini adalah tempat yang sangat modern, memiliki kapasitas 1.194 kursi, diatur dengan standar internasional yang tinggi dalam semua aspeknya, termasuk panggung besar, tempat orkestra, dan fly tower. Ciputra Artpreneur Jakarta juga sangat unik karena memiliki keragaman jenis dan fungsi bangunan yakni terdiri dari Theater, Museum, dan Gallery. 


\subsection{Program Ruang dan Analisa Site a. Program Ruang}

Penentuan jenis ruang didapatkan berdasarkan dari hasil studi lapangan dan studi literatur yang telah dikaji, sehingga dapat menentukan zona inti, zona sekunder, zona servis dan zona pelayanan. Zonazona tersebut akan dirancangan khususnya untuk Perencanaan \& Perancangan Gedung Pertunjukan Seni Tari Tradisional Suku Dayak di Kota Samarinda tipe sebagai berikut:

1. Zona Inti :

Aula pertunjukan, Ruang Latihan Tari, Ruang Latihan Besar, Area Cinderamata Khas Suku Dayak, Ruang Pameran, Ruang Pakaian, Ruang Properti, Ruang Ganti, Ruang Make Up, Ruang Control Suara \& Cahaya

2. Zona penunjang :

Food Court dan Musholla

3. Zona Sevis :

Pos Penjaga, Loker tiket, Toilet Umum, ATM Center, Sarana Air Bersih (Tower), Sarana Air Bersih (Water Harvesting), TPS, IPAL, Parkir Motor, Parkir Mobil, Parkir Bus, Loading dock, Drop Area

Tabel 1. Rekapitulasi Luas Total Bangunan

\begin{tabular}{|c|c|c|c|}
\hline No & Fasilitas & Bangunan & Luas \\
\hline 1. & Fasilitas Utama & Gedung Pertunjukan Tari & $3.655,132 \mathrm{~m}^{2}$ \\
\hline 2. & Fasilitas Penelola & Gedung Penelola & $950,810 \mathrm{~m}^{2}$ \\
\hline 3. & Fasilitas Penunjang & $\begin{array}{l}\text { Gazebo } \\
\text { Foodcourt } \\
\text { Musholla }\end{array}$ & $784.430 \mathrm{~m}^{2}$ \\
\hline 4. & Fasilitas Lain-Lain & $\begin{array}{l}\text { Servis } \\
\text { Parkir }\end{array}$ & $4.491,175 \mathrm{~m}^{2}$ \\
\hline \multicolumn{3}{|c|}{ Total Luas Keseluruhan } & $9.881,550 \mathrm{~m}^{2}$ \\
\hline
\end{tabular}

\section{b. Analisa Site}

Pada Gedung Pertunjukan Seni Tari Tradisional Suku Dayak di Kota Samarinda, lokasi tapak berada di kawasan perumahan, di mana terletak di JL. Bukit Alaya, Kota Samarinda, Kalimantan Timur. Kawasan perencanaan bebrsebelahan dengan perumahan dan pemukiman yang secara fasilitas di dekat kawasan merupakan daerah yang cukup lengkap dan terdapat beberapa hotel didekat kawasan perencanaan tapak.

Lokasi tapak yang dipilih untuk Gedung Pertunjukan Seni Tari Tradisional Suku Dayak di Kota Samarinda bagian utara yaitu terletak di Kecamatan Samarinda Utara, pemilihin ini berdasarkan beberapa hal berikut: (1) Keseesuaiannya dengan peraturan Pemkot Surabaya tentang Rencana Tata Ruang Wilayah (RTRW) dalam pasal 21 ayat 3a; (2) Lokasi tapak yang berada dekat dengan jalan Besar kota kota sehingga aksesnya mudah; (3) Lokasi tapak yang merupakan lahan kosong yang berada di JL. Bukit Alaya, Kota Samarinda, Kalimantan Timur yang kondisinya dekat dengan besar kota, sehingga mempermudah pencapaian.

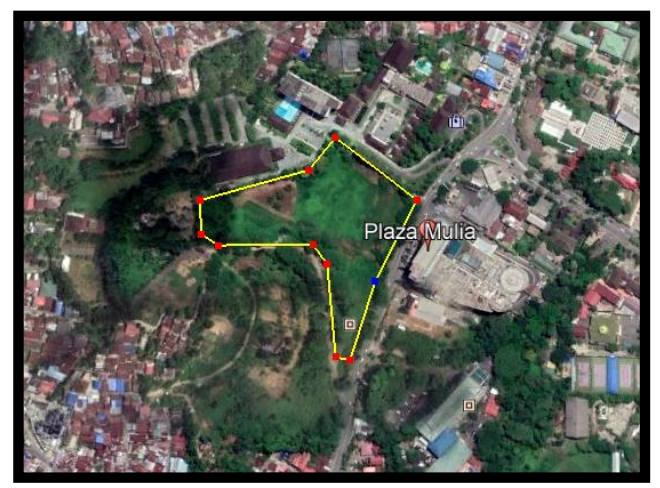

Gambar 8. Lokasi Site/Tapak 


\subsection{Program dan Konsep Rancangan \\ a. Program Rancangan}

Dalam menghasilkan suatu rancangan yang efektif dan efisien, maka dalam proses merancang harus terarah dan berjalan sebagaimana mestinya. Arah dari rancangan tersebut berupa program rancangan yang didalamnya berupa gambarangambaran dalam bentuk sketsa dan bahasa verbal. Berdasarkan teori yang dikemukakan oleh Donna P. Duerk, program rancangan yang baik menurutnya adalah program rancangan yang berbicara tentang benda dan proses, sedangkan proses tersebut adalah:

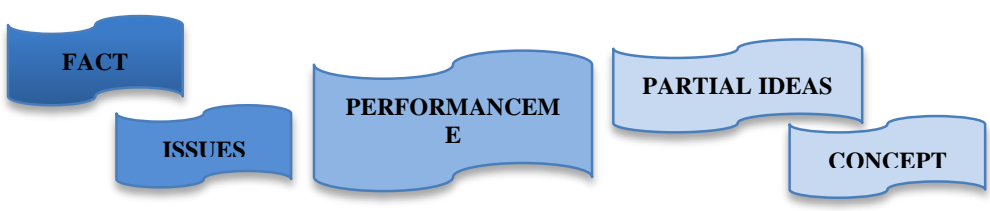

Gambar 9. Diagram tahapan proses perancangan

\section{b. Konsep Rancangan}

Beberapa tahap dalam menerapkan konsep perancangan yang digunakan adalah: (1) Penggunaan tema Arsitektur neo-Vernakular, tidak hanya menerapkan elemen-elemen fisik yang diterapkan dalam bentuk modern tapi juga elemen non fisik seperti budaya, pola pikir, kepercayaan, tata letak, religi dan lain-lain; (2) Penerapan konsep makroyaitu Develop Culture, yaitu Menciptakan desain Kompleks Gedung Pertunjukan Seni Tari Tradisional Suku Dayak Di Kota Samarinda Edukasi di Kota Samarinda sebagai pusat kesenian tari tradisional di Kota Samarinda dan juga sebagai daya tarik wisatawan ke samarinda yang di dalamnya terdapat desain tatanan lahan, desain bentuk, desain ruang yang tujuan melestarikan unsur-unsur lokal yang telah terbentuk secara empiris oleh sebuah tradisi yang kemudian sedikit atau banyaknya mangalami pembaruan menuju suatu karya yang lebih modern atau maju tanpa mengesampingkan nilai-nilai tradisi setempat; dan (3) Penajaman Konsep pada konsep tatanan lahan, konsep bentuk, konsep ruang, berupa:

(a) Cultural Realm pada tatanan lahan, dengan menciptakan desain tatanan lahan yang menerapkan sebuah kawasan yang memiliki suasana nyaman dan asri serta menerapkan nilai-nilai budaya Suku Dayak pada kawsan, dengan penerapan banyak vegetasi peneduh dapat mengurangi hawa panas yang berlebih ke dalam kawasan.

(b) Forward Culture pada bentuk bangunan, dengan Menciptakan desain bentuk bangunan dengan konsep budaya yang maju, agar dapat memberikan semangat untuk mengembangkan kebudayaaan khas daeerah.

(c) Adaptive pada ruang, di mana dalam Arsitektur menciptakan desain ruang secara langsung maupun tak langsung berhubungan dengan ruang, ruang yang berfungsi sebagai wadah kegiatan.

\subsection{Hasil Rancangan}

\section{a. Tatanan Lahan}

Desain tatanan lahan di mulai dari pembagian zoning yang selanjutya di jadikan sebuah block plan. Dalam sebuah blockplan ada pembagian zona, yaitu zona pengunjung, zona pengelola, dan zona servis. Adapun aspek yang harus di perhatikan dalam desain tatanan lahan yakni ruang terbuka hiijau yang di terapkan sekitar $60 \%$ pada rancangan ini.

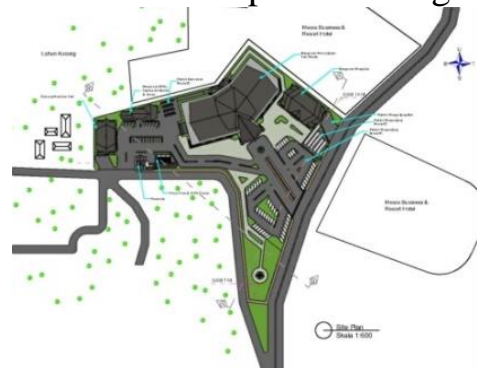

(a)

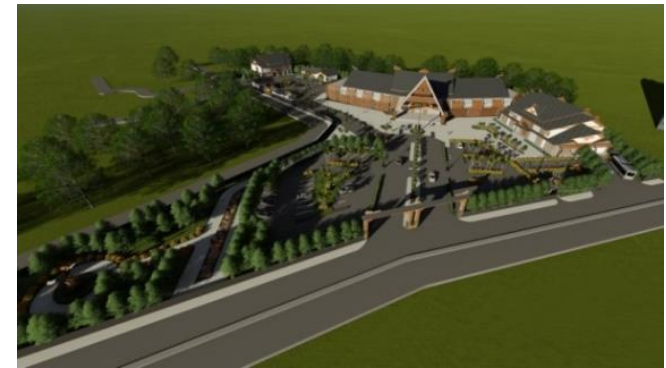

(b)

Gambar 10. (a) Site Plan; dan (b) 3d Kawasan 


\section{b. Desain Bentuk}

\section{Bangunan 1 (Gedung Pertujukan Tari Khas Suku Dayak)}

Pemberian secondary skin yang mencolok dan menjadi vocal point pada rancangan ini. Secondary skin ini menggunakan ACP berwarna coklat agar tetap unity pada sekitarnya, dan penerapan atap plana asli dari rumah adat Dayak di terapkan ke dalam bentuk bangunan kebudayaan ini.

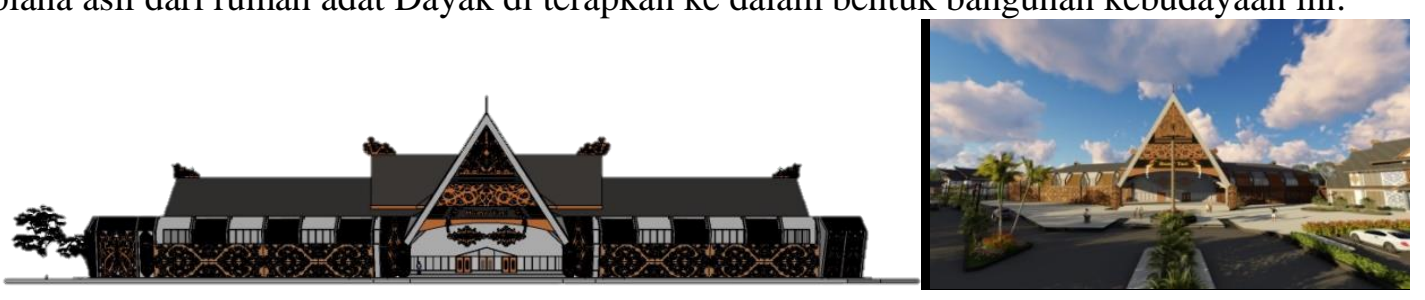

(a)

(b)

Gambar 11. (a) Tampak Gedung Pertunjukan Tari; dan (b) 3d Gedung Pertunjukan Tari

\section{Bangunan 2 (Gedung Pengelola)}

Pemberian secondary skin diterapkan juga pada bangunan pengelola ini dan menjadi vocal point pada rancangan ini. Penerapan atap plana asli dari rumah adat Dayak di terapkan ke dalam bentuk bangunan kebudayaan ini dengan konsep Neo Vernakular menjadikan bentukan bangunan ini terlihat seperti bentukan atap yang bertingkat-tingkat.

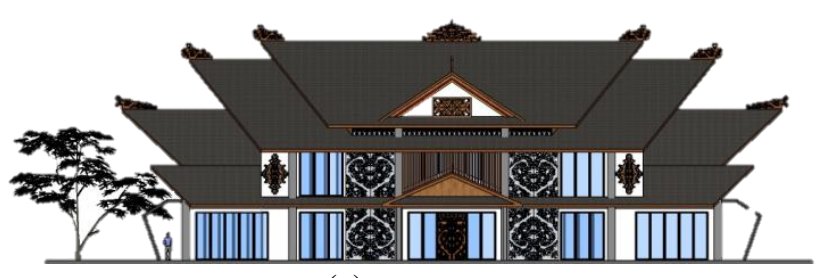

(a)

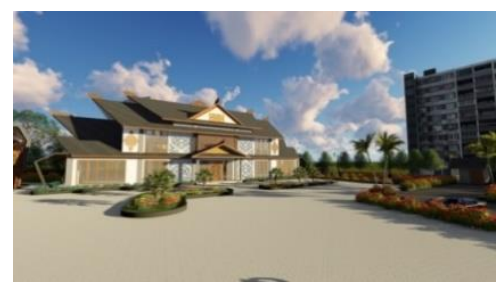

(b)

Gambar 12. (a) Tampak Gedung Pengelola; dan (b) 3d Gedung Pengelola

\section{Bangunan 3 (Gedung Pelatihan Tari)}

Pada desain bentuk bangunan pelatihan tari ini masih mengambil bentukan dari rumah adat Dayak, yang mana bentukan atap banguna mengambil dari bentukan atap rumah adat Dayak dan penerapan secondary skin yang mengikutin ukiran Khas dari Suku Dayak.

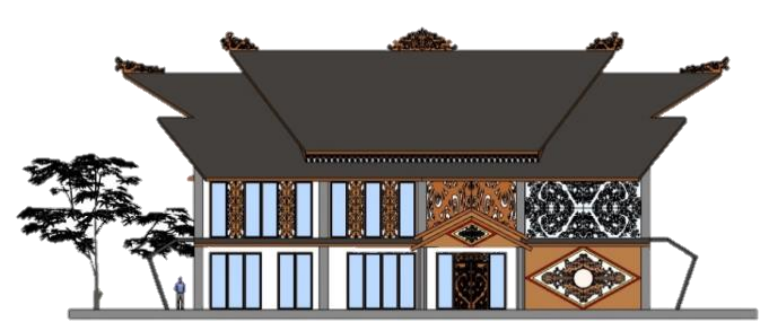

(a)

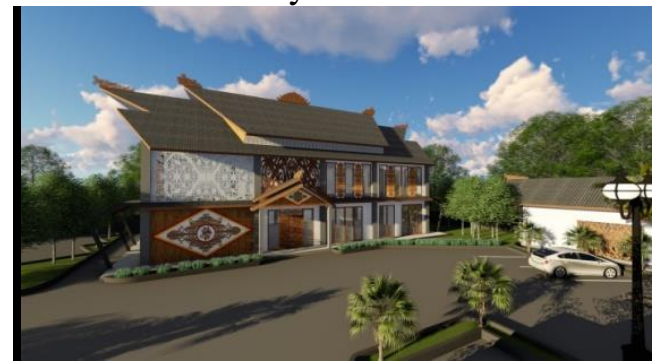

(b)

Gambar 13. (a) Tampak Gedung Pelatihan Tari; dan (b) 3d Gedung Pelatihan Tari

\section{c. Desain Ruang}

Fasilitas Gedung Pertunjukan Seni Tari Tradisional Suku Dayak di Kota Samarinda memiliki beberapa fasilitas berupa ruang pertunjukan tari tradisional Suku Dayak, pakaian adat tradisional, seni ukir ornament, alat music khas suku Dayak dan kerajinan Tenun. Dengan konsep "Adaptive" dalam Arsitektur menciptakan desain ruang secara langsung maupun tak langsung berhubungan dengan ruang, ruang, konsep ini sendiri di tujukan agar ruang-ruang pada rancangan ini mampu beradaptasi dengan lingkungan ruang luarnya. 


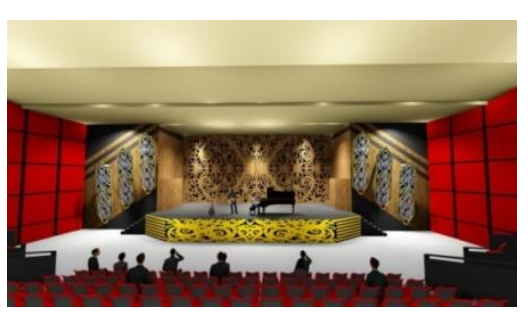

(a)

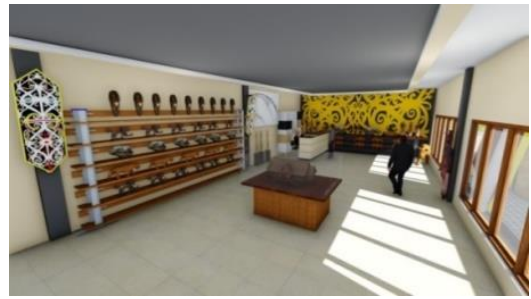

(b)

Gambar 14. (a) Interior Pertunjukan Tari, (b) Interior Ruang Cinderamata

\section{Kesimpulan}

Gedung Pertunjukan Seni Tari Tradisional Suku Dayak di Kota Samarinda ini mengusung budaya Suku Dayak di Kalimantan Timur dimana mampu untuk menjadi wadah pusat pegelaran tarian adat khas Suku Dayak di Kalimatan timur. Dengan menggunakan konsep makro develop culture dapat memberikan desain tatanan lahan, desain bentuk, desain ruang yang tujuan melestarikan unsur-unsur lokal yang telah terbentuk secara empiris oleh sebuah tradisi. Gedung pertunjukan seni tari tradisional di Samarinda ini memiliki keunikan dalam desain nya salahsatu nya pada bagian fasad bangunan pertunjukan seni tari terdapat ornament ukiran khas suku Dayak yang sedikit miring kedepan sebagai simbolis bahwa budaya khas daerah dapat selalu berkembang kedepannya dan juga bangunan ini diharapkan dapat menarik para wisatawan buat berkunjung ke Samarinda untuk melihat keunikan dari warisan budaya Suku Dayak khas Kalimantan Timur.

Gedung Pertunjukan Seni Tari Tradisional Suku Dayak di Kota Samarinda, Kalimantan Timur dengan pendekatan tema arsitektur Neo Vernakular dan menggunakan konsep "Develop Culture" ini diharapkan menjadi obyek pengembangan budaya denga tarian khas adat Suku Dayak yang diharapkan dapat memberikan kontribusi positif bagi lingkungan dan masyarakat serta dapat menjadi obyek wisata bagi masyarakat, baik dari dalam maupun luar negeri yang tertarik tentang tarian kebudayaan asli Kalimantan Timur di Kota Samarinda.

\section{Referensi}

Fauzan, C. D., \& Prayogi, W. L. (2020). Penerapan Arsitektur Neo - Vernakular Pada Bangunan Fasilitas Budaya Dan Hiburan. Jurnal Arsitektur ZONASI, Vol.3 (No.3), 2621-1610. https://scholar.google.com/scholar?hl=id\&as_sdt=0\%2C5\&q=Chaesar+Dhiya+Fauzan\%2C+Wi di+Luthfi+Prayogi\%2C+\%282020\%29+Penerapan+Arsitektur+Neo++Vernakular+Pada+Bangunan+Fasilitas+Budaya+Dan+Hiburan+No.3.+Vol.3\&btnG=

Ghina Fajrine, Agus Budi Purnomo,Jimmy Siswanto Juwana, Penerapan Konsep Arsitektur Neo Vernakular Pada Stasiun Pasar Minggu, Seminar Nasional Cendekiawan ke 3 Tahun 2017, Buku 2

Lail, J., \& Widad, R. (2015). Belajar Tari Tradisional Dalam Upaya Meletarikan Tarian Asli Indonesia. Jurnal Inovasi Dan Kewirausahaan, Vol.4(No.2), 102-104. https://scholar.google.com/scholar?hl=id\&as_sdt=0\%2C5\&q=Jamalul+Lail\%2C+Romzatul+Wi $\mathrm{dad} \% 2 \mathrm{C}+\% 282015 \% 29+$ Belajar+Tari+Tradisional+Dalam+Upaya+Meletarikan+Tarian+Asli+I ndonesia\%2C+No.+2+Vo1.++4+\&btnG=

Sanjaya, A., \& Kartono, J. L. (2014). Pusat Informasi Pariwisata dan Kebudayaan Kalimantan Timur di Samarinda. Jurnal Edimensi Arsitektur, Vol. II (No.1), 285-292. http://publication.petra.ac.id/index.php/teknik-arsitektur/article/view/1675

Singarimbun, M. (1991). Beberapa Aspek Kehidupan Masyarakat Dayak. No.3. https://journal.ugm.ac.id/jurnal-humaniora/article/view/2083

Tutuko, P. (2005). Proses Berpikir Dalam Mengkomunikasikan Perencanaan Dan Pemrograman Arsitektur. Jurnal Rekayasa Perencanaan, Vol.1 http://eprints.upnjatim.ac.id/2495/1/Pindo_Tutuko.pdf 